\title{
SBÍRKA KRAMÁŘSKÝCH TISKŮ KNIHOVNY NÁRODNÍHO MUZEA
}

\author{
Eva Ryšavá (Praha)
}

Oddělení knižní kultury Knihovny Národního muzea uchovává ve svých fondech největší sbírku kramářských tisků v České republice, která dosahuje mezinárodního významu. Tato sbírka obsahující převážně písně má téměř 40 tisíc jednotlivých drobných tisků a jejich souborů v tzv. špalíčcích. Jako celek představuje unikátní doklad mimořádného rozšiření jedné odnože české lidové kultury spojující folklorní píseň s vlivy umělé literatury. Umožňovala to především gramotnost širokých lidových vrstev, jejich hudebnost a obliba zpěvu. Mohutnost tiskové produkce kramářských písní dokazuje skutečnost, že zvláště v 18. století žily některé malé tiskárny pouze z výroby těchto písní.

Kramářské tisky se dostávaly do muzejní knihovny již od založení Vlastenského (dnes Národního) muzea roku 1818. Nebylo to však výsledkem cílevědomého budování knižního fondu, což měla zajistit instrukce Instruktion für den Bibliothekar des Vaterländischen Museums und Dienstordnungsbestimmung in demselben, vypracovaná za účasti Josefa Dobrovského. ${ }^{1}$ Knihovna měla mít vědecký charakter a měla též vybudovat českou národní knihovnu. Tento návrh vypracoval Josef Dobrovský roku 1823 a obsahoval nejen knihy a rukopisy týkající se Čech, ale i mapy, portréty a podobné památky. ${ }^{2}$

Je pochopitelné, že v těchto nárocích na vysokou úroveň muzejních knihovních fondů nedostaly místo drobné lidové tisky, považované tehdy za pout'ové a jarmareční zboží. Jejich obsah byl v době romantismu považován za pravý opak zidealizované čisté lidové tvorby. Ale ani fondy požadované $\mathrm{v}$ instrukcích se nezískávaly bez potíží, protože zřizovatelem muzea byla soukromá Společnost vlastenského muzea v Čechách, závislá na darech a příspěvcích svých příznivců. ${ }^{3} \mathrm{~V}$ počátečních letech tak byla knihovna odkázána na dary knižních sbírek šlechtických mecenášů a př́spěvky a dary obětavých vlastenců, které zajišt'ovali v každém kraji dobrovolníci zvaní ,sběratelé“. Př́inosem byly též odkazy a pozůstalosti. $V$ těchto darech nejrůznějšího charakteru se našly i kramářské písně, které byly umístěny v knihovně, ale i v archivu a historických sbírkách muzea.
Situace se však změnila $v$ době bachovského absolutismu v 50. letech 19. století, kdy po potlačení předchozích revolucí zavládl v Rakouském císařství tuhý policejní režim. $\mathrm{V}$ roce 1854 dostalo pražské policejní ředitelství od zemského gubernia prríkaz, aby odevzdávalo muzeu všechny publikace, které prošly cenzurním řízením. Knihovna tak obdržela ohromné množství tisků, které by jinak do svých fondů nezačlenila. Mezi nimi byl i značný počet kramářských tisků. Vedení knihovny je přijalo z povinnosti, aniž by tušilo, že budoucnost je ocení jako jedinečný historický pramen. Tyto tisky totiž obsahovaly cenzurní záznamy, které podávají přesný obraz metody a cílů tehdejší cenzurní praxe. Předpokládali bychom, že pozornost se věnovala zvláště zpravodajským písním, zatímco náboženské nebyly tak bedlivě zkoumány. Záznamy v písních však svědčí o tom, že i náboženský obsah mohl být podezřelý (např́klad závadným bylo shledáno oslovení Panny Marie jako císařovny). ${ }^{4}$

V druhé polovině 19. století také prudce vzrůstá tisková produkce a přibývá tisků neknižní povahy. Tyto tiskoviny spolu s písemnými dokumenty (např. pozůstalostmi spisovatelů) byly v knihovně shromažd'ovány v tzv. Literárním archivu.

Špalíčky v lidových vazbách byly v řadě případů rozvazovány na jednotlivé výtisky, čímž nenávratně zmizela jejich vypovídací hodnota, svědčící o zájmech jejich majitelů a šíření kramářské produkce. Ke konci 19. a začátkem 20. století byly naopak v knihovně z jednotlivých tisků vytvářeny špalíčky umělé podle jejich témat, například vojenské, náboženské, milostné, nebo podle autora (F. Hais).

Úroveň muzejní sbírky a její osudy závisejí z velké míry na osobnosti a úrovni jejího správce. Kramářským tiskům přálo štěstí, protože se o ně zajímaly na základě svého odborného zaměření vedoucí osobnosti knihovny. Pamětníci vzpomínali, že soubor kramářských tisků byl dokonce umístěn prrímo $\mathrm{v}$ ředitelské pracovně. Pro kulturního historika, etnografa a bibliografa Čeňka Zíbrta (v knihovně pracoval v letech 1892 až 1927) byly podkladem nesčetných článků ve sborníku Český lid, jehož byl redaktorem, i samostatných

\footnotetext{
VRCHOTKA 1967, s. 36-38.

2 Český překlad uvádí VRCHOTKA 1967.

3 Mezi prvními dárci byla „paní kněžna“ Kateřina Zaháňská s částkou 7500 zlatých. Naskýtá se otázka, zda o tom Božena Němcová, věrná příznivkyně a spolupracovnice muzea, věděla.

4 Viz BEZDĚK - RYŠAVÁ 1983.
} 
studií. Zíbrt též v Českém lidu vydal paměti nejznámějšího písničkáře 19. století Františka Haise, jejichž rukopis je uložen v rukopisné sbírce knihovny. ${ }^{5}$

Ředitel knihovny Josef Volf, historik a knihovník (v knihovně v letech 1903 až 1937), čerpal ve svých pracích z českých kulturních dějin často ze sbírky kramářských tisků. Ve 30 . letech dal podnět $\mathrm{k}$ jejich soustředění od roku vydání 1774 do samostatné sbírky a k jejich uspořádání. Starší kramářské tisky byly převedeny do sbírky starých tisků. Uspořádání bylo na tehdejší dobu novátorské - podle incipitů, a prozrazovalo již odborný zájem o tento druh tiskové produkce. Na obalech kramářských písní se prováděla také jejich katalogizace. Mimořádný zájem o kramářské tisky měl i další ředitel knihovny, literární historik a editor Miloslav Novotný (v knihovně v letech 1924 až 1951). Z muzejní sbírky dokonce vydal dva výbory. ${ }^{6}$

Pro sbírku kramářských tisků byl významný rok 1937, kdy vyšla základní práce Bedřicha Václavka a Roberta Smetany České písně kramářské. ${ }^{7}$ Dvojice vědců - literární teoretik Václavek a muzikolog Smetana - v ní poprvé zhodnotila kramářskou tvorbu celkově jako významný historický jev, který nestojí níže než folklorní lidová píseň, ale naopak ji obohacuje a rozvíjí novým obsahem a životním rozhledem. Autoři též zdůraznili mimořádný sociální dosah této produkce. Oběma spolupracovníkům přitom pomáhala katalogizace kramářských písní prováděná v Knihovně Národního muzea. Zatímco Bedřich Václavek byl umučen roku 1943 v Osvětimi, Robert Smetana se zvláště v posledních letech svého života (zemřel roku 1988) živě zajímal o muzejní sbírku a o práci na bibliografii kramářských písní 19. století, která z ní vycházela.

Druhou světovou válku přežila sbírka kramářských tisků bez úhony. Po roce 1945 se započalo s budováním jejího hlavního katalogu podle incipitů a s ním i pomocných katalogů místa tisku, vročení, tiskařů, autorů a nápěvů. Obsahovou stránku písní zachycoval předmětový katalog s velmi komplikovanou strukturou, která znesnadňovala jeho běžné používání. V 50. letech 20. století v knihovně panovaly obavy o osud sbírky, protože většina kramářských písní měla náboženský obsah. Naštěstí byla chráněna silnou autoritou umučeného komunistického vědce Bedřicha Václavka a skutečností, že kramářské písně měly velký vliv na autory dělnických písní. Pro zkoumání tohoto jevu byla hojně využívána právě muzejní sbírka kramářských tisků. ${ }^{8}$

Univerzita Palackého v Olomouci pořádala od roku 1960 vědecké konference s názvem Václavkova Olomouc. V roce 1961 a 1964 byly hlavním tématem kramářské a zlidovělé písně. $\mathrm{Na}$ obou konferencích vystoupil pracovník Knihovny Národního muzea dr. Karel Bezděk, který seznámil se stavem a zpracováním muzejní sbírky kramářských tisků a navrhl pravidla jejich popisu pro národní bibliografii 19. století. ${ }^{9}$ Do centra pozornosti se tak dostala sbírka kramářských tisků Knihovny Národního muzea, která měla být základem pro budoucí bibliografii. Na její zpracování měly navazovat záznamy $\mathrm{z}$ dalších institucí uchovávajících kramářské tisky. S tehdejší Státní knihovnou ČSSR - Národní knihovnou bylo dohodnuto, že tyto tisky budou tvořit samostatnou část bibliografie. ${ }^{10}$

Po založení Muzea knihy v roce 1957, které obrátilo pozornost na fondy neknižní povahy, bylo v roce 1969 v Knihovně Národního muzea založeno nové oddělení knižní kultury, které dostalo za úkol soustředit právě tyto doklady z 19. a 20. století. Hlavním iniciátorem zrrízení tohoto oddělení byl pracovník knihovny, teoretik umění dr. Miloslav Bohatec (1913-1967). Do fondů nového pracoviště se dostala i sbírka kramářských tisků. Vedením byl pověřen dr. Karel Bezděk a na nové místo odborného pracovníka, přidělené ministerstvem pro zpracování bibliografie 19. století, nastoupila absolventka knihovnictví Fakulty osvěty a novinářství UK Eva Ryšavá. Byla navázána spolupráce s dalšími, hlavně muzejními knihovnami, které bud' přímo zapůjčily, nebo zpřístupnily své fondy kramářských tisků pro vytváření bibliografie. Každý výtisk byl srovnáván se sbírkou Knihovny Národního muzea a práce postupovala rychle kupředu, takže již v roce 1970 mohlo být na Václavkově Olomouci referováno o prvních výsledcích a zkušenostech. ${ }^{11} \mathrm{O}$ dalším postupu pak byla veřejnost informována zejména ve Sborníku Národního muzea v Praze, radě C-Literární historie. ${ }^{12}$

Sbírka kramářských tisků nebyla a není uzavřeným fondem, ale stále roste novými nákupy, dary a odkazy. Velkou roli při tom hráli (a snad budou i nadále hrát) soukromí sběratelé, kteří v době nezájmu vědeckých institucí o tuto okrajovou produkci zachraňovali kramářské tisky před zkázou. V roce 1977 např́ílad obdržela Knihovna Národního muzea jako odkaz vzácnou knižní sbírku sběratele Bohuslava Duška (1886-1957), v níž byl cenný soubor kramářských písní, zejména z revolučních událostí roku $1848 .^{13}$

Zcela zásadním obohacením fondu kramářských tisků bylo získání významné sbírky učitele, bibliofila, sběratele, archiváře a muzejníka Rudolfa Hlavy (1911-1988). Podle jeho prání ji potomci nabídli Národnímu muzeu, do kterého postupně přicházela v letech 1989, 1993 a 2003. Sběratelské zájmy Rudolfa Hlavy byly široké, sbíral staré tisky, rukopisy, exlibris, lidové písně i hudebniny, ale jeho největší láskou byly kramářské písně. Hlava připomínal nadšené obrozenské učitele, kteří svým životem a prací obětavě a nezištně sloužili národu. Svou sbírku považoval za majetek celého národa a sebe skromně za zachránce dokladů jeho bohaté kultury. Proto byla jeho sbírka otevřena všem zájemcům. Hlava úzce

\footnotetext{
${ }^{5}$ ZÍBRT 1908, 1909 a 1910.

${ }^{6}$ NOVOTNÝ 1930 a NOVOTNÝ 1940.

${ }^{7}$ SMETANA - VÁCLAVEK 1937.

${ }^{8}$ Viz např. KARBUSICKÝ - PLETKA 1958.

${ }^{9}$ BEZDËK 1963.

${ }^{10}$ BEZDĚK 1965.

${ }^{11}$ RYŠAVÁ 1972.

12 RYŠAVÁ 1974. BEZDĚK - RYŠAVÁ 1983.

${ }^{13}$ VRCHOTKA et al. 1978.
} 
spolupracoval s vědeckými institucemi a pro Knihopis českých a slovenských tisků od doby nejstarši do konce XVIII. století, vydávaný tehdejší Československou akademií věd, poskytl na 1000 bibliografických záznamů tisků, z nichž mnohé byly unikáty. Jeho sbírka kramářských tisků, obsahující 12000 kramářských písní a 44 špalíčků, je zachována jako samostatný fond nesoucí před každou signaturou jméno R. Hlavy. ${ }^{14}$

Snahou oddělení knižní kultury je též soustředění kramářských tisků z jednotlivých oddělení Národního muzea do sbírky kramářských tisků $\mathrm{v}$ muzejní knihovně. V roce 2016 byla do knihovny převedena první část sbírky kramářských tisků z oddělení národopisu ( 878 jednotek). Převod těchto tisko̊ z Náprstkova muzea nebyl dosud uskutečněn, ale je k dispozici jejich seznam.

Sbírka kramářských písní v Knihovně Národního muzea sloužila od počátku jak vědeckým pracovníkům a studentům, tak širokému okruhu zájemců o kramářskou produkci. Prameny a inspiraci pro svou tvorbu v ní však nacházeli a stále nacházejí i umělci, z nichž jmenujeme například spisovatele Bohumila Hrabala a muzikology Jiř́ho Traxlera, Jiřího Tichotu a Přemysla Ruta. Zájem o kramářskou tvorbu a její autory byl též vyvolán vydáním pamětí nejznámějšího pražského písničkáře Františka Haise, jejichž rukopis je uchováván v Národním muzeu. ${ }^{15}$

Knihovna Národního muzea jako složka muzea plní již od svého založení také úkoly muzejní, což znamená, že kromě budování, zpracování a zpř́istupňování svých fondů je rovněž prezentuje $\mathrm{v}$ expozicích a na výstavách. Kramářské tisky se v minulosti stávaly součástí zejména národopisných expozic, širší uplatnění našly teprve v Muzeu knihy, otevřeném roku 1957 v tehdejším státním zámku (bývalém klášteře cisterciáků) ve Žd'áru nad Sázavou. Toto muzeum, jehož spoluzakladatelem byl významný knihovník a literární historik Bohumír Lifka (1900-1987), sehrálo v dalších desetiletích důležitou roli i v mezinárodním měřítku jako speciální instituce pro moderní prezentaci vývoje písma a knihy od počátků po současnost. V roce 1992 byl zámek vrácen v restituci rodině Kinských. Prof. Radslav Kinský (19282008) měl v tradicích svého rodu (kníže Rudolf Kinský byl prvním protektorem a mecenášem Matice české) blízký vztah k Národnímu muzeu a pro Muzeum knihy vytvořil mimořádně výhodné podmínky. Po padesáti letech však jeho expozice potřebovaly nákladnou obnovu a prostředí historické budovy již nevyhovovalo současným požadavkům na ochranu sbírek. Proto bylo v roce 2014 rozhodnuto činnost muzea ukončit.

Pracovníci oddělení knižní kultury se svým vedoucím dr. Karlem Bezděkem usilovali o to, aby kramářským tiskům byl dán větší prostor $\mathrm{k}$ samostatné prezentaci kramářské tvorby, která by ji ukázala v celé její šírí a rozmanitosti. V roce 1977 připravili k poctě nedožitých 80 . narozenin
Bedřicha Václavka v hlavní muzejní budově výstavu kramářských písní s názvem Poslyšte mládenci, též $i$ panny. Výstava ukazovala vývoj české kramářské tvorby pomocí originálních tisků, zvětšenin jejich dřevořezové výzdoby a přepisů textů do latinky, původních štočků, hudebních nástrojů, dobových reprodukcí a literatury.

Živý ohlas, který výstava způsobila ve veřejnosti i sdělovacích prostředcích, přiměl Knihovnu Národního muzea, aby ji nabídla svému družebnímu partnerovi v tehdejší NDR Muzeu knihy a písma při Německé knihovně v Lipsku. Pro tento účel byla doplněna písněmi německými z vlastní sbírky, které byly tištěny a rozšiřovány na českém území. Bližší průzkum německé části fondu přinesl i některá nová zjištění, potvrzující těsnou spojitost a vzájemné ovlivňování české a německé kramářské tvorby. ${ }^{16}$ Výstava se konala $\mathrm{v}$ roce 1978 a setkala se s př́zznivým přijetím četných návštěvníků. Zaregistroval ji a zhodnotil i odborný tisk v NDR. ${ }^{17}$

V dalších letech se kramářské tisky uplatňovaly na výstavách v Muzeu knihy (např. o českých sběratelích) a menších samostatných výstavách v bývalém Kabinetu knižní kultury v hlavní muzejní budově (Bohuslav Dušek, František Hais). Dostaly své místo také v rozhlasových a televizních pořadech (České zlidovělé písně, Bedřich Václavek, František Hais).

Masivní nástup počítačové techniky začátkem 21. století a rozvoj informačních a komunikačních technologií zahájily též novou etapu práce s muzejními sbírkami. Pro kramářské tisky to znamenalo, podobně jako v Národní knihovně ČR ukončení retrospektivní bibliografie 19. století v klasické lístkové formě a její nahrazení výběrovou bibliografií v podobě internetové knihovny kramářských tisků s názvem Špalíček. ${ }^{18}$ Digitalizace sbírky byla zahájena v oddělení knižní kultury v roce 2008 na základě grantu Ministerstva kultury. Špalíček dosud zahrnuje 4000 kramářských tisků a konvolutů (desetina celé sbírky) a jejich výběr proporčně dodržuje obsah sbírky. Autoři zdůrazňují výhodnost této formy pro uživatele virtuálním zpřístupněním kramářských tisků a současně jejich ochranou. Do tohoto projektu získávají i další instituce se svými fondy kramářských tisků a snaží se o jejich co největší počet. V budoucnosti by tato internetová knihovna mohla navázat na projekt národní retrospektivní bibliografie a pokračovat v ní.

Nové technologie zasáhly i výstavní činnost a jejich užití se ukázalo zvlášt' užitečné v mimořádných situacích, jako byla epidemie koronaviru. Jedině tak mohli návštěvníci v době uzavření muzea aspoň virtuálně zhlédnout aktuální výstavu oddělení knižní kultury Korona v Muzeu!. Uplatnily se na ní ve velké míře kramářské tisky - písně a modlitby ke svaté Koroně. ${ }^{19}$

Kramářská tvorba a kramářské tisky nabývají na významu v současné době, kdy se odborníci obracejí od velkých dějinných událostí ke zkoumání všedního dne širokých

\footnotetext{
${ }^{14}$ ČERMÁKOVÁ 1994.

15 Prvních pět dílů vydal Čeněk Zíbrt v Českém lidu v letech 1908, 1909 a 1910 (viz pozn. 5). Další dva díly, které se do Národního muzea dostaly později, viz RYŠAVÁ 1979. Výbor z celých pamětí vyšel pod názvem Vzpomínky pražského pisničkáre, viz RYŠAVÁ 1985.

16 RYŠAVÁ 1980.

17 SCHAEFER 1978.

18 BYDŽOVSKÁ 2012.

${ }^{19}$ Za informace o činnosti oddělení knižní kultury v posledních letech děkuji PhDr. Pavlu Muchkovi, Mgr. Matěji Měřičkovi a Michalu Klackovi.
} 
lidových vrstev. Jedním z mála autentických svědectví o této dosud málo známé zóně lidského života v minulosti je právě kramářská tvorba. Sbírka kramářských tisků Knihovny Národního muzea je svým rozsahem a unikátní skladbou mimořádně významným pramenem pro tento výzkum a její zpracování a zpřístupnění by mělo patřit $\mathrm{k}$ předním úkolům nejen knihovnictví a historie, ale i celé české kultury.

\section{Seznam použité literatury:}

BEZDĚK 1963: BEZDĚK, Karel. Stav a zpracování sbírek kramářských tisků. In: DVOŘÁK, Jaromír - KVAPIL, Josef (edd.). Václavkova Olomouc 1961: sborník referátů a diskusních přispěvků o kramářské písni. Praha: Státní pedagogické nakladatelství, 1963, s. 343-346.

BEZDĚK 1965: BEZDĚK, Karel. Popis kramářských tisků v bibliografii 19. století. In: DVOŘÁK, Jaromír SMETANA, Robert (edd.). Václavkova Olomouc 1964: $k$ soudobé problematice zlidovělých písní. Ostrava: Profil, 1965, s. 117-120.

BEZDĚK - RYŠAVÁ 1983: BEZDĚK, Karel - RYŠAVÁ, Eva. České kramářské písňové tisky, jejich bibliografické zpracování a ukázka bibliografie 19. století. Sborník Národního muzea v Praze, r̆ada C-Literární historie 28, 1983, č. 4, s. 173-201.

BYDŽOVSKÁ 2012: BYDŽOVSKÁ, Iva. Digitální knihovna kramářských tisků Špalíček. In: KRUŠINSKÝ, Rostislav (ed.). Problematika historických a vzácných knižních fondi̊ Čech, Moravy a Slezska: sbornik z 20. odborné konference Olomouc, 20. - 21. záři 2011. Olomouc: Vědecká knihovna v Olomouci, s. 29-38.

ČERMÁKOVÁ 1994: ČERMÁKOVÁ, Marta. Rudolf Hlava - sběratel kramářských písní. Antique 1994, č. 6, s. 8. KARBUSICKÝ - PLETKA 1958: KARBUSICKÝ, Vladimír - PLETKA, Václav. Dělnické písně. Díl 1-2. Praha: Státní nakladatelství krásné literatury, hudby a umění, 1958.

NOVOTNÝ 1930: NOVOTNÝ, Miloslav. Písničky jarmareční většinou výpravné a vesměs starodávné ze sbirek Knihovny Národního musea. Praha: Erna Janská, 1930.

NOVOTNÝ 1940: NOVOTNÝ, Miloslav. Špalíček písniček jarmarečních. Praha: Evropský literární klub, 1940.

RYŠAVÁ 1972: RYŠAVÁ, Eva. Kramářské písně v programu činnosti regionálních kulturních institucí. In: VALOUCH,
František - DVOŘÁK, Jaromír (edd.). Václavkova Olomouc 1970: o socialistické kultuře a regionalismu. Ostrava: Profil, 1972, s. 201-202.

RYŠAVÁ 1974: RYŠAVÁ, Eva. Práce na bibliografii kramářských písní 19. století v Knihovně Národního muzea v Praze. Sborník Národního muzea v Praze, rada CLiterární historie 19, 1974, č. 1-2, s. 31-35.

RYŠAVÁ 1979: RYŠAVÁ, Eva. Paměti pražského písničkáře Františka Haise. Sborník Národního muzea v Praze, řada C-Literární historie 24, 1979, č. 1-2 a 3-4.

RYŠAVÁ 1980: RYŠAVÁ, Eva. Německá předloha písně „Po půl noci, dřív než kohout“ (Příspěvek ke studii Bedřicha Václavka). Časopis Národního muzea v Praze, rada historická 149, 1980, č. 3-4, s. 171-176.

RYŠAVÁ 1985: RYŠAVÁ, Eva (ed.). HAIS, František. Vzpominky pražského písničkáře: 1818-1897. Praha: Odeon, 1985.

SCHAEFER 1978: SCHAEFER, Helma. Vom Sieg der Türken bis zur schönen Minka. Mitteilungen aus dem wissenschaftlichen Bibliothekswesen der Deutschen Demokratischen Republik 16, 1978, č. 6, s. 40-41.

SMETANA - VÁCLAVEK 1937: SMETANA, Robert VÁCLAVEK, Bedřich. České písně kramářské. Praha: František Borový, 1937.

VRCHOTKA 1967: VRCHOTKA, Jaroslav. Déjiny Knihovny Národního muzea v Praze: 1818-1892. Praha: Státní pedagogické nakladatelství, 1967.

VRCHOTKA et al. 1978: VRCHOTKA, Jaroslav et al. Knihovna Bohuslava Duška. Sborník Národního muzea v Praze, řada C-Literární historie 23, 1978, č.1-4, s. 78-91.

ZÍBRT 1908: ZÍBRT, Čeněk. Písničkář František Hais a jeho paměti. Český lid 17, 1908, s. 214-224, 273-284, 356-366, 418-440.

ZÍBRT 1909: ZÍBRT, Čeněk. Písničkář František Hais a jeho paměti. Český lid 18, 1909, s. 150-157, 250-254, 289-297, 342-351, 371-389, 413-437.

ZÍBRT 1910: ZÍBRT, Čeněk. Písničkář František Hais a jeho paměti. Český lid 19, 1910, s. 7-20, 87-100, 147156, 193-201, 239-246, 289-296, 389-397, 451-469.

Eva Ryšavá 